\title{
НЕКОТОРЫЕ ЗАКОНОМЕРНОСТИ ОБРАЗОВАНИЯ И РАЗМЕЩЕНИЯ ПОЛИМЕТАЛЛИЧЕСКИХ РУДОПРОЯВЛЕНИИ В ЦЕНТРАЛЬНОЙ ЭСТОНИИ
}

Проведенные в писледние годы исследования позволили обосновать перспективы рудоносности Центральной Эстонии в полосе контакта нижнесилурийских и среднедевонских отложений в пределах ПярнуНаровской тектонической зоны (Судов, 1973), а также доказать приуроченность полиметаллического оруденения на южном склоне Балтийского щита к зонам платформенной тектонической активизации, секущим породы кристаллического фундамента и осадочного чехла (Пуура, Судов, 1976).

Проведенные в 1972-1975 гг. буровые, геофизические и геохимические работы в районах Лаэва, Острику и Выхма (рисунок) позволили получить необходимые материалы для изучения факторов, контролирующих размещение полиметаллического оруденения в карбонатной части разреза оса́дочных пород.

Наиболее важным рудоконтролирующим фактором является тектонический. Все полиметаллические рудопроявления Центральной Эстонии располагаются в пределах Пярну-Наровской зоны платформенной тектонической активизации, представляющей собой серии прерывистых, часто кулисообразно расположенных тектонических дислокаций, секущих весь разрез осадочных пород и унаследованных от более древних тектонических разломов в кристаллическом фундаменте. Общая ширина зоны в пределах Центральной Эстонии колеблется от 50 до 60 км. Тектонические нарушения имеют в основном северо-восточное простирание, котоpoe в полосе современного контакта нижнесилурийских и среднедевонских отложений изменяется иногда до субширотного.

Полиметаллические рудопроявления приурочены к конкретным тектоническим нарушениям, имеющим, как правило, крутые углы падения. Это хорошо видно на примерах скважин районов Лаэва, Ныва, Кахала, Острику, Кынну и др., которые, будучи пройденными по падению нарушений, вскрывают рудоподводящие каналы в ордовико-силурийских карбонатных породах.

Установленные в ходе поисковых работ ареалы распространения повышенных концентраций свинца, цинка, меди представляют собой полосы, вытянутые по простиранию рудоносных тектонических нарушений, подзон и зон. Отмечается телескопированный характер геохимических аномалий на разных литолого-стратиграфических уровнях в пределах тектонических нарушений. 
В районе Лаэва бурением в сочетании с разведочными работами методами дипольного электрического профилирования и вертикального электрического зондирования, а также геохимическими исследованиями установлена четкая приуроченность полиметаллического оруденения к крутопадающим тектоническим зонам Метсанука и Лаэва, секущим весь палеозойский карбонатный разрез. Ширина зон составляет 1,5-2 км, протяженность $3,5-4 \kappa м$.

Большой фактический материал позволяет считать доказанным отсутствие полиметаллических рудопроявлений, ареалов и ореолов свинца, цинка и меди вне зон тектонических нарушений.

Вторым важным фактором, контролирующим размещение полиметаллического оруденения на территории Центральной Эстонии, является литологический характер пород.

Установлено, что полиметаллические рудопроявления преимущественно приурочены к доломитам, доломитизированным известнякам, реже мергелям, испытавшим вторичную доломитизацию в зонах тектонических нарушений. Наиболее крупные скопления полиметаллических руд отмечены в крупнозернистых, кавернозных, иногда брекчиевидных породах.

В разрезе карбонатных пород Центральной Эстонии выделяются следующие горизонты, в которых существовали благоприятные условия для рудоотложения: наровский, адавереский, райккюлаский, поркуниский, набалаский и раквереский. Слюдистые кварцевые песчаники пярнуского горизонта также были подходящими для образования полиметаллических руд.

Наиболее крупные рудопроявления наблюдаются в Центральной Эстонии в окрестностях Выхма, Лаэва, а также Острику, Кахала, Кынну, Пуйату, Ныва.

Третьим фактором, контролирующим размещение полиметаллических рудопроявлений в разрезе осадочных пород, является структурный. Его значение состоит в том, что все отмеченные рудопроявления образовались под современным или палеоэкраном мергелистых пород среднего девона. Это подтверждается профилем буровых скважин в районе Лаэва. Здесь для рудовмещающих доломитов адавереского горизонта характерно интенсивное развитие прожилково-вкрапленного оруденения, прнчем прожилки имеют самую разнообразную ориентировку. В мергелистых породах нижней части наровского горизонта прожилки распространены значительно реже, имеют субвертикальную ориентировку и выклиниваются в пределах первых 10 от контакта с адаверескими породами.

Полиметаллические рудопроявления района Выхма, располагающиеся к северу от современного контакта среднедевонских и нижнесилурийских пород, представляют собой уцелевшие в ходе послесреднедевонской континентальной денудации пород жкорневые» части богатых скоплений полиметаллических руд.

Геохимические и гидрогеохимические аномалии свинца, цинка, меди выявленные к юго-западу от Выхма (рисунок) на вероятном продолже нии сюда рудоносных тектонических зон под экраном среднедевонски) пород, подтверждают возможное нахождение здесь богатых скоплениі. полиметаллических руд.

Благоприятные для рудоотложения структурные условия были также и на других участках современного или палеоконтакта среднеордовикских и нижнесилурийских пород, в частности в районе Острику.

Четвертым фактором, оказывающим положительное влияние на рудоотложение сульфидов металлов, является палеогеографический. Его влияние проявляется в тех карбонатных породах, которые в период, предшествовавший рудообразованию, находились в зоне выветривания, а 
затем были перекрыты трансгрессивными отложениями среднего девона. Эти карбонатные породы обычно трещиноватые и сильнокавернозные. Это хорошо видно на примере доломитов адавереского горизонта, обнажающихся в русле р. Навести (район Выхма). Растворение карбонатов и образование каверн происходило до вторичной доломитизации пород и сульфидообразования. Такое же явление отмечается на рудопроявлениях Ваки, Острику, Кахала и др.

Имеющийся материал позволяет также более определенно высказаться по вопросу гипотезы образования полиметаллических рудопроявлений.

Гипотеза гидротермального или телетермального происхождения полиметаллических рудопроявлений Эстонии, и в том числе оруденения в Центральной Эстонии, имеет много сторонников (Orviku, 1935; Гатальский, 1959; Соловьев, 1959; Пальмре, 1960; Möls, 1961; Гончаров, 1964; Вахер и др., 1964; Судов, 1973). Расходясь лишь частично в оценке времени и температуры образования руд, источников рудного вещества, вышеуказанные исследователи приводят обоснованные доказательства в пользу гидротермального или телетермального происхождения полиметаллических руд. Основными из них являются следующие: четкая приуроченность рудопроявлений к зонам тектонических нарушений, сквозной характер рудной минерализащии, секущей отложения разного возраста и тектонического плана от наровских отложений среднего девона до пород кристаллического фундамента включительно, значительный вертикальный размах оруденения (до нескольких сотен метров), морфология рудоносных зон и рудных тел (субвертикальные линзы и ленты, секущие осадочные отложения), вторичная дорудная доломитизация карбонатных пород в зонах тектонических нарушений, окварцевание и милонитизация вмещающих пород, наличие нескольких рудных генераций и зональность рудоотложения, многокомпонентный состав руд и их первичных ореолов, включающий такие характерные для гидротермальных руд элементы, как йод, ртуть, таллий, а также сурьму, олово, которые присущи активизированным тектоническим зонам Северо-Запада CCCP.

Некоторые исследователи (Газизов, 1971; Нечаев, 1974; Попов, 1970; и др.) считают, что полиметаллические рудопроявления Эстонии имеют осадочное происхождение, указывая на стратифицированный характер оруденения. Однако до сих пор признаки стратифицированных залежей на территории Эстонии нигде не установлены.

Источником сульфидов является, по мнению некоторых авторов осадочной гипотезы, концентрация тяжелых металлов в бассейне осадконакопления с последующим их диагенетическим и эпигенетическим перераспределением. Однако этот тезис не согласуется с результатами геохимических исследований наиболее перспективных для рудоотложения пород. Повышенные концентрации свинца, цинка и меди в породе вне тектонических зон не установлены. Также не установлен вынос рудных элементов из пород, находящихся в относительно стабильных блоках карбонатных отложений.

Простота минерального состава эстонских рудопроявлений, выдвигаемая в защиту осадочной гипотезы, явление кажущееся, в действительности число гипогенных рудных минералов в полиметаллических рудопроявлениях к настоящему времени превышает 10, а число рудных генераций составляет $2-5$.

Анализ имеющихся материалов позволяет предположить, что наиболее вероятным путем образования свинцово-цинковых рудопроявлений 

Центральной Эстонии и южного склона Балтийского щита в целом было осаждение свинца, цинка, меди и их элементов-спутников из слабоминерализованных растворов, которые поступали вверх по зонам тектонических нарушений в периоды тектонической активизации Северо-Запада Русской платформы (Пуура, Судов, 1976).

В ходе движения этих растворов происходило многократное смешивание их с глубинными подземными водами. Сам процесс перемещения растворов через водоупорные слои, по-видимому, мог бы быть объяснен за счет явлений гидровулканизма (Иванчук, 1974; Парк, Мак-Дормид, 1966), совпадавших с периодами тектонической активизации ПярнуНаровской тектонической зоны. Основными формами его проявления были трещинный инъекционный гидровулканизм в изолированный водоносный комплекс и в открытый комплекс.

В изолированных водоносных комплексах условия для осаждения более крупных скоплений руд были благоприятные. Именно этим объясняется наличие богатых свинцово-цинковых рудопроявлений под экраном мергелистых пород наровского горизонта среднего девона и в полосе современного и палеоконтакта девонских и силурийских пород в Центральной Эстонии. Широко распространенная в зонах тектонических нарушений вторичная доломитизация карбонатных пород, по-видимому, является фронтальной волной трещинного инъекционного гидровулканизма, за счет которого в вышележащие отложения были привнесены значительные количества магния из глубокозалегающих водоносных горизонтов.

Все вышеизложенное позволяет положительно оценить перспективы обнаружения промышленных скоплений полиметаллических руд в полосе контакта среднедевонских и нижнесилурийских отложений в пределах зон тектонических нарушений Центральной Эстонии.

\section{ЛИТЕРАТУРА}

В ахер Р. М., Кууспалу Т. И., Пуу ра В. А., Эрисалу Э. К. 1964. О геологическом положении сульфидных рудопроявлений в районе Ульясте. В сб.: Литология палеозойских отложений Эстонни. Таллин.

Г а з и з о в М. С. 1971. Карст и его влияние на горные работы. М.

Га т а льски й М. А. 1959. Микродислокация и трещиноватость пород в районе Прибалтики и их значение в миграции и распределении флюидов. Тр. ВНИГРИ, вып. 131, геол. сб., № 4.

Го н ч а ро в Г. С. 1964. Проявления полиметаллического оруденения Эстонской ССР. Сов. геология, № 7 .

И в ан чук П. П. 1974. Роль гидровулканизма в формировании газоконденсатных и газонефтяных месторождений. М.

Н е ч е в С. В. 1974. Флюоритно-барито-сульфидная формация запада Русской платформы. Киев.

П ал ь м р е Х. Г. 1960. Закономерности полиметаллического оруденения на территории Эстонской ССР. В кн.: Закономерности размещения месторождений в платформенных чехлах, ч. 4. Киев.

П а р К Ч. Ф., М а к-Д ор м и д Р. А. 1966. Рудные месторождения. М.

По по в В. М. 1970. Проблемы генезиса стратифицированных месторождений цветных металлов. В сб.: Состояние и задачи советской литологии, т. II. М.

П у у р а В., С удов Б. О зонах платформенной тектонической активизации южного склона Балтийского щита и их металлогении. Изв. АН ЭССР, Хим. Геол., 25, № 3.

С оло в ь в В. Г. 1959. Полиметаллическая минерализация в Эстонии по данным опробования керна скважин и обнажений коренных пород. Инф. сборник ВИТР, № 21.

С удо в Б. А. 1973. Свинцово-цинковые рудопроявления на территории Эстонской ССР и их перспективы. Разведка и охрана недр, № 3. 
Möls, E. 1961. Eesti aluspõhja lōhede geneesist. Geol. kogumik. Tartu.

Orviku, K. 1935. Viljandimaa aluspōhi ja pinnakate. Koguteos «Eesti» VII, Viljandimaa. Tartu Ulik. Geol. Inst. Toim., nr. 47.

Управление геологии

Совета Министров Эстонской ССР

Поступила в редакцию 25/V 1976

\section{B. SUDOV}

\section{KESK-EESTI POLUMETALLILISTE MAAGIILMINGUTE TEKKE JA PAIKNEMISE SEADUSPARASUSI}

Laeva, Ostriku ja Vōhma maagiilmingute pōhjal käsitletakse Kesk-Eesti polümetallilist maagistumist mõjustavaid tegureid. Näidatakse, et maagiilmingute lokaliseerumist pōhjustavad tektoonilised, litoloogilised ja paleogeograafilised tegurid. Nendest andmetest lähtudes viidatakse maagi leidmise võimalusele Navesti jōe piirkonnas ja toetatakse Eesti polümetallilise maagi teletermaalse tekke hüpoteesi.

\section{B. SUDOV}

\section{REGULARITIES OF THE FORMATION AND DISTRIBUTION OF POLYMETAL ORE PHENOMENA IN CENTRAL ESTONIA}

On the basis of specimens from some Central Estonian localities (Laeva, Ostriku and Võhma) the factors controlling polymetal orification in Central Estonia were examined. It was stated that the localization of the ore was due to tectonical, lithological and palaeogeographical factors. The prospects of detecting polymetal ore in the region of Navesti, in the north-west of Võhma, were studied. A hypothesis concerning the telethermal origin of Estonian polymetal ore has been adopted. 